\title{
Unravelling migratory connectivity in marine turtles using multiple methods
}

\author{
Brendan J. Godley ${ }^{1 *}$, Castro Barbosa ${ }^{2}$, Michael Bruford ${ }^{3}$, Annette C. Broderick ${ }^{1}$, \\ Paulo Catry ${ }^{4}$, Michael S. Coyne ${ }^{1,5}$, Angela Formia ${ }^{3,6}$, Graeme C. Hays ${ }^{7}$ and Matthew J. Witt ${ }^{1}$ \\ ${ }^{1}$ Marine Turtle Research Group, Centre for Ecology and Conservation, University of Exeter, Cornwall Campus, UK; \\ ${ }^{2}$ Instituto da Biodiversidade e das Áreas Protegidas, Bissau, Guinea Bissau; ${ }^{3}$ Biodiversity and Ecological Processes \\ Research Group, Cardiff School of Biosciences, Cardiff University, Cardiff CF10 3TL, UK; ${ }^{4}$ Eco-ethology Research \\ Unit \& Centro de Biociências, ISPA, Rua Jardim do Tabaco 34, 1149-041 Lisboa, Portugal; 5 SEATURTLE.org, 1 \\ Southampton PI, Durham, NC 27705, USA; ${ }^{6}$ Dipartimento di Biologia Animale e Genetica, University of Florence, Via \\ Romana 17, 50125 Firenze, Italy; and ${ }^{7}$ Institute of Environmental Sustainability, Swansea University, Singleton Park, \\ Swansea SA2 8PP, UK
}

\begin{abstract}
Summary
1. Comprehensive knowledge of the fundamental spatial ecology of marine species is critical to allow the identification of key habitats and the likely sources of anthropogenic threats, thus informing effective conservation strategies.

2. Research on migratory marine vertebrates has lagged behind many similar terrestrial animal groups, but studies using electronic tagging systems and molecular techniques offer great insights.

3. Marine turtles have complex life history patterns, spanning wide spatio-temporal scales. As a result of this multidimensional complexity, and despite extensive effort, there are no populations for which a truly holistic understanding of the spatial aspects of the life history has been attained. There is a particular lack of information regarding the distribution and habitats utilized during the first few years of life.

4. We used satellite tracking technology to track individual turtles following nesting at the green turtle Chelonia mydas nesting colony at Poilão Island, Guinea Bissau; the largest breeding aggregation in the eastern Atlantic.

5. We further contextualize these data with pan-Atlantic molecular data and oceanographic current modelling to gain insights into likely dispersal patterns of hatchlings and small pelagic juveniles.

6. All adult turtles remained in the waters of West Africa, with strong connectivity demonstrated with Banc D'Arguin, Mauritania.

7. Despite shortcomings in current molecular markers, we demonstrate evidence for profound sub-structuring of marine turtle stocks across the Atlantic; with a high likelihood based on oceanographic modelling that most turtles from Guinea-Bissau are found in the eastern Atlantic.

8. Synthesis and applications. There is an increased need for a better understanding of spatial distribution of marine vertebrates demonstrating life histories with spatio-temporal complexity. We propose the synergistic use of the technologies and modelling used here as a working framework for the future rapid elucidation of the range and likely key habitats used by the different life stages from such species.
\end{abstract}

Key-words: marine protected areas, molecular ecology, ocean current modelling, satellite tracking, spatial ecology

\section{Introduction}

Migration, typically between breeding and non-breeding locations, is a phenomenon widespread in vertebrates. This is

*Correspondence author. E-mail: b.j.godley@exeter.ac.uk especially true among birds, where the greatest strides have been made towards describing and understanding the underlying mechanisms (reviewed by Berthold, Gwinner \& Sonnenschein 2003). It remains a challenge to understand the degree of migratory connectivity between breeding and non-breeding areas; a factor that undoubtedly has profound 
evolutionary, ecological and conservation implications. Recent advances in tracking using chemical, genetic and electronic tags have begun to give insights into connectivity in birds (Webster et al. 2002; Bearhop et al. 2005). These techniques have also been ported into the study of other groups of migratory species in both the terrestrial and marine realms.

Research in the spatial ecology of migratory marine vertebrates has lagged behind many similar terrestrial animal groups and has inhibited progress in their conservation (Block et al. 2005). Comprehensive knowledge of the spatial ecology of these species is critical to allow the identification of key habitats and the likely sources of anthropogenic threats, thus informing effective conservation strategies (Cooke 2008). Movement studies, using electronic tagging systems, have highlighted the likely impacts of threats in wide-ranging species of marine fishes (Lutcavage et al. 2000; Block et al. 2005), reptiles (Godley et al. 2008), birds (Åkesson \& Alerstam 1998) and mammals (Mate, Nieukirk \& Kraus 1997; Thompson, Moss \& Lovell 2003). Molecular techniques also offer tremendous insights (Moritz 1994; Avise 1998; Palumbi \& Cipriamo 1998).

Marine turtles are of global conservation concern, mandating increased knowledge of their at-sea ecology. Although there is some diversity in developmental patterns (Bolten 2003a), typically, hatchling sea turtles leave the natal beach and swim offshore and remain in oceanic habitats for several years. In some populations and species, they then recruit to a series of neritic habitats, while for others oceanic living prevails (Godley et al. 2008). Irrespective, life cycles typically involve movements over large temporal and spatial scales (see Musick \& Limpus 1997 for review). There have been significant insights into most life stages of loggerhead turtles Caretta caretta Linnaeus nesting in the western north Atlantic (Bolten 2003b) but despite extensive efforts, as a result of multidimensional complexity, there are no populations for which a truly holistic understanding of the spatial aspects of the life history has been attained. There is a particular lack of information regarding the distribution and habitats utilized during the first few years of life by all sea turtle species (Hamman et al. in press).

Technology has begun to transform the study of this animal group. Using satellite transmitters, it has been possible to detail the migration routes and location and usage of foraging grounds of large juvenile to adult turtles, in neritic (Luschi et al. 1998; Tröeng et al. 2005) and pelagic areas (James, Ottensmeyer \& Myers 2005). In addition, the technique has highlighted that in some populations, individuals demonstrate a range of strategies (Hawkes et al. 2006; McLellan \& Read 2007; Seminoff et al. 2008). As a result of natal philopatry in both sexes (Meylan, Bowen \& Avise 1990; FitzSimmons et al. 1997a,b) genetic markers have given significant insights into the global phylogeography of the adults of several species (Bowen et al. 1992, 1994, 1998; Dutton et al. 1999). Subsequent sampling away from breeding sites has highlighted how feeding assemblages in oceanic (Bowen et al. 1995; Bolten et al. 1998) and neritic (Bass \& Witzell 2000; Luke et al. 2004; Bowen et al. 2007) habitats are typically of mixed origin.

The green turtle Chelonia mydas Linnaeus has feeding and nesting areas largely lying in the tropics and has been subject to centuries of direct exploitation (Parsons 1962). As a result, the species is of high conservation concern, although some populations are rebounding following the reduction of direct take (Balazs \& Chaloupka 2004, Tröeng \& Rankin 2005; Broderick et al. 2006). Among the major green turtle nesting colonies in the Atlantic is Poilão Island, Guinea-Bissau (Catry et al. 2002, 2009); the largest breeding aggregation in the eastern Atlantic. Despite extensive tagging over the last decade, only six tag returns have been obtained away from the colony: three from Mauritania, one from Senegal, one from Gambia and one from mainland coast of Guinea Bissau (C. Barbosa unpublished data), and knowledge of the spatial ecology for this population and all others in West Africa is, as yet, embryonic.

Against this background we set out to use satellite tracking technology to track individual turtles following nesting at Poilão with our fundamental aim to ascertain foraging grounds and migratory corridors for this population, with an ancillary aim to gain insights into habitat utilization between nesting events. We further contextualize these data with pan-Atlantic molecular data and oceanographic current modelling to gain insights into likely dispersal patterns of hatchlings and small pelagic juveniles. We propose this synergistic use of technologies as a working framework for the future rapid elucidation of the range and likely key habitats used by the different life stages from this and other marine species demonstrating such spatiotemporal complexity.

\section{Materials and methods}

\section{STUDY SITE}

The study is based around the green turtle nesting population of the island of Poilão, the southernmost of the Bijagós Archipelago, Guinea-Bissau $\left(10^{\circ} 30^{\prime}-11^{\circ} 0^{\prime} \mathrm{N}, 15^{\circ} 30^{\prime}-15^{\circ} 48^{\prime} \mathrm{W}\right.$; West Africa; Fig. 1a,b). The nesting biology of this population has been more fully elaborated in Catry et al. (2002, 2009).

\section{SATELLITE TRACKING}

Between 21 and 23 November 2001, we attached satellite transmitters to 10 post-nesting green turtles according to methodology detailed in Godley et al. (2002). We utilized two models of transmitter [Telonics ST-18 Platform Terminal Transmitters (PTTs) $n=6$ and Telonics ST-6 PTTs $n=4$ (Mesa, Arizona, USA)]. Transmitters were tracked using the Argos system and data were interpreted and analysed using the Satellite Tracking and Analysis Tool program from SEATURTLE.ORG (Coyne \& Godley 2005). To contextualize movements, bathymetric data were obtained for the study areas from the General Bathymetric Chart of the Oceans (GEBCO, http://www. bodc.ac.uk/projects/international/gebco/gebco_digital_atlas).

\section{MOLECULAR TRACKING}

To generate a molecular profile of the rookery, we used data from 51 samples gathered from emergent hatchlings for a total of 42 hatching nests and nine nesting females and analysed for a $488 \mathrm{bp}$ fragment at the $5^{\prime}$ end of the mtDNA control region (Formia et al. 2006) and data were combined with those from 19 additional samples from the same site (Encalada et al. 1996). These data were compared with 

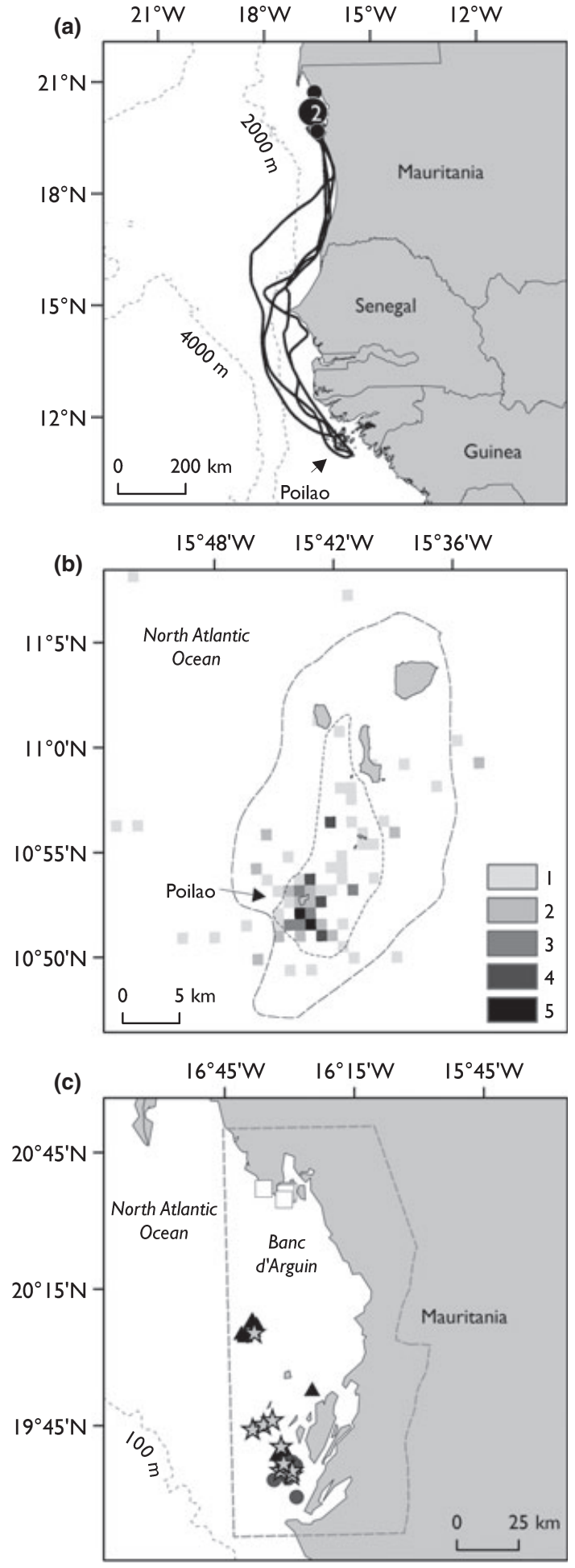

Fig. 1. Insights from satellite tracking. (a) Post-nesting movements of four turtles tracked to their foraging sites in Mauritania. Routes plotted using location classes 3, 2, 1, and A with maximum $5 \mathrm{~km} \mathrm{~h}^{-1}$ filter. (b) Habitat utilization during the internesting interval. Density of occupation days per $\mathrm{km}^{2}$ ). Initial locations were obtained from Argos data using classes 3, 2, 1, A and B subjected to a maximum $5 \mathrm{~km} \mathrm{~h}^{-1}$ filter. Midday positions were interpolated using the assumption of straight line movement. Marked are the limits of the inner and outer zone of the João Viera e Poilão National Marine Park. (c) Foraging ground utilization of four turtles tracked to the coastal waters of Mauritania. Marked are the limits of the Banq D'arguin National Park. available haplotype frequencies of conspecific nesting and foraging sites within the Atlantic, ensuring the same fragment of the control region had been sequenced. We carried out mixed stock analysis using the program BAYEs (Masuda 2001; Pella \& Masuda 2001; Bolker et al. 2003), which applies Monte Carlo Markov Chain (MCMC) methods and Bayesian estimation to calculate the probability density distribution for stock mixture proportions.

\section{CURRENT MODELLING}

Aviso geostrophic velocity vector (GVV) data, based on mean absolute dynamic topography, were used to model ocean currents (http:// www.aviso.oceanobs.com/). The Aviso product has a spatial resolution of one-third of a degree and temporal resolution of 7 days from 2000 to early 2003, 3.5 days until mid-2008 and daily thereafter. These data were used to provide insight in to how passively drifting objects might be distributed by ocean currents in the region. Virtual particles were placed in the GVV field. Although the source GVV data are available in 7 day, 3.5 day and daily time steps, particles were advected every $6 \mathrm{~h}$ to prevent a particle moving a distance greater than the spatial resolution of the underlying GVV data (approximately $36 \mathrm{~km}$ at this latitude). No information was available on the movement of neonate hatchlings after leaving the beaches of Guinea-Bissau, so, particles were released at seven positions around the archipelago to simulate a range of possible insertion points into the pelagic environment (Fig. 2, inset). Release positions were off the continental shelf and ranged between 323 and $405 \mathrm{~km}$ from Poilão. A new set of particles was released each day from 15 September to 15 January for each of the seasons beginning in the years 2001-2006 (approximately coinciding with peak emergence of green turtle hatchlings at this site), for a total of 861 particles per season.

The $u$ and $v$ ocean current vector components were sampled at the location of each particle from the next closest GVV data file in time using a bilinear interpolation [Generic Mapping Tools (GMT)]. The $u$ and $v$ values $\left(\mathrm{cm} \mathrm{s}^{-1}\right)$ were converted to $\mathrm{m} \mathrm{day}^{-1}$ and the particle advected that distance in the $x$ and $y$ direction, respectively, and a new location obtained for that particle (see animation in Fig. S1, Supporting information.

Particles that left the GVV field (i.e. pushed towards the coastline) were removed from the model as there is no information on how a neonate hatchling would behave in this situation. The model was run for 850 days ( 2 years from the release of the last particle during each season) per run. One location per day was saved for each particle for analysis. These data were gridded on a $1 \times 1$ degree lattice to provide a summary of the distribution of particles and the number of days particles were present in each grid cell. All current modelling was carried out using custom perl scripts, the GEOD program, part of the PROJ.4 Cartographic Projections Library (http://www.remotesensing.org/ proj/) and the GMT package (Wessel \& Smith 1991).

\section{Results}

\section{SATELLITE TRACKING}

Within a few weeks of deployment, satellite tracking can allow significant insights into the spatial ecology of highly mobile marine fauna at remote locations at different phases of their migratory cycle. Firstly, insights were obtained into habitat use around the nesting site during the inter-nesting intervals. Turtles lay multiple clutches in any given season and although 
efforts were made to select females which had been tagged earlier in the season, only three individuals left immediately following the nesting attachment. We were thus able to record the utilization of the waters around Bijagós Archipelago by seven individual turtles during one $(n=5)$ or two $(n=2)$ internesting intervals for a total of 115 turtle days. For most individuals this meant most, if not all, of their time between nesting was spent within the boundaries of the João Vieira and Poilão National Marine Park (Fig. 1b) with $82.6 \%$ of all turtle days being spent within the park (outer zone, 16.5\%; inner zone $66 \cdot 1 \%)$.

Secondly, post-nesting migration routes were highlighted (Fig. 1a) for this species for the first time in West Africa. Of the eight individuals for which post-nesting movements were recorded (transmissions were lost from two individuals immediately following the subsequent nesting), four females migrated from Poilão to the Park National du Banc D’Arguin, Mauritania (Fig. 1a), where they remained until the transmitter units failed. This involved travel over $>1000 \mathrm{~km}$ in all cases through the coastal and near coastal waters of Gambia, Senegal and Mauritania. In all four of these individuals, part of the journey was through oceanic waters which would have precluded neritic feeding. The remaining four individuals were recorded making shorter-range movements following nesting to locations within the Bijagos archipelago suggesting local residence.

Thirdly, insights into foraging behaviour in the heart of an extensive marine park in Banc d'Arguin, Mauritania was revealed. For the duration of transmissions (83, 50, 36 and 44 days respectively), individual turtles A-D showed a degree of fidelity to shallow water foraging areas (Fig. 1c).

\section{CURRENTS}

A total of 861 virtual 'particles', representing passively drifting neonate sea turtles, were released at an array of pelagic locations around the Bijagós Archipelago in each of six seasons 2001/2002-2006/2007 and tracked for a maximum of 850 days. Particle tracks lasted an average of 259 days ( $\pm 245 \cdot 0$ SD, range: $10-850$ days). For an animation of particle movements see Fig. S1 (Supporting information). The majority of particles were retained within coastal and oceanic waters adjacent to West Africa between Mauritania and Cameroon, primarily within the Sierra Leone Basin and Cape Verde Plateau $(n=4481 ; 86.8 \%)$ and the Gulf of Guinea $(n=526 ; 10 \cdot 2 \%$; Fig. 2). Fifteen $(0 \cdot 3 \%)$ particles became entrained in the South Equatorial Current and $30(0.6 \%)$ were carried as far as the coast of Brazil. A total of 77 (1.5\%) particles entered the North Equatorial Current and were carried eastward before slipping in to the Equatorial Counter Current and returning to the Eastern Tropical Atlantic. Thirty-six particles $(0.7 \%)$ approached the Canary Current to the north of the Bijagos Archipeligo. There was some variation amongst years, with more particles carried south to the Gulf of Guinea in 2001,2005 and $2006(21 \cdot 4 \%, 16 \cdot 3 \%$ and $17 \cdot 3 \%$ respectively) and fewer in 2002, 2003 and $2004(3.1 \%, 1 \cdot 6 \%$ and $1.4 \%$

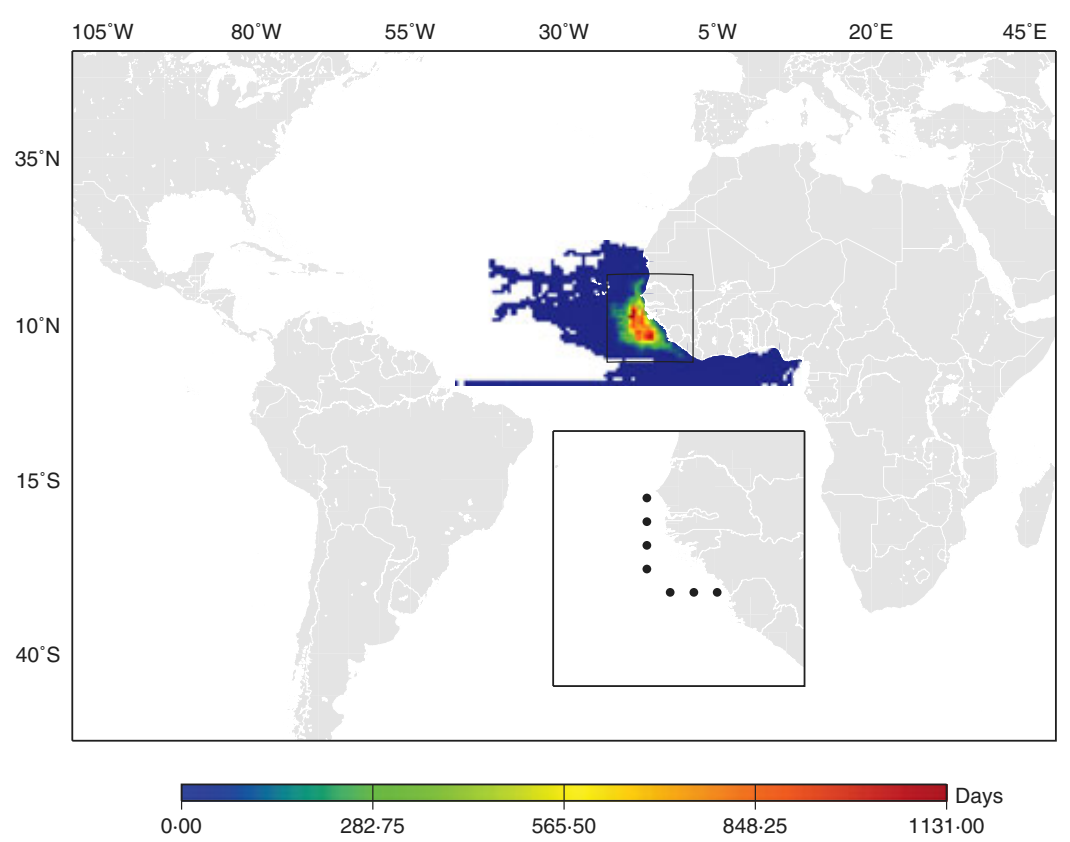

Fig. 2. Insights from Oceanographic Current Modelling. The mean distribution of virtual hatchlings after deployment in modelled oceanic locations around Poilão, Guinea Bissau. Particles were released during six different years (2001/2002 to 2006/2007) and advected on a dynamic ocean current field for a maximum duration of 850 days. A total of 5166 particles were tracked from all six seasons. Duration of individual particle trajectories was variable as particles left the current field when they reached the coastline. Inset box shows particle release locations around the Bijagos Archipeligo. Release locations were a sufficient distance from the coast to fall into the modelled current field which is absent very near shore. For an animation of 1 year's particles see Fig. S1(Supporting information) and for raster of each year's data see Fig. S2 (Supporting information). 

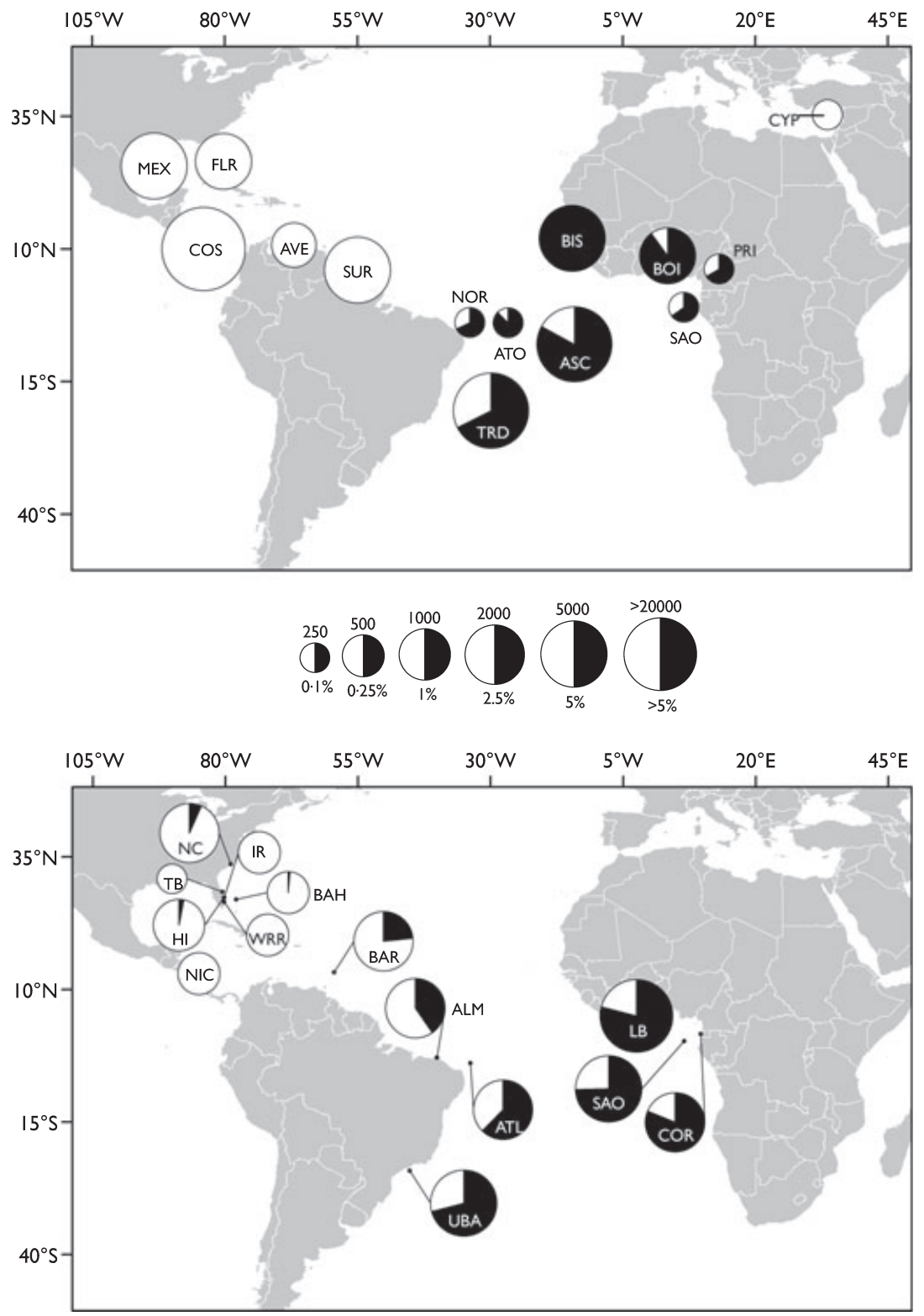

Fig. 3. Insights from Molecular Analyses. (a) Relative frequency of mtDNA haplotype CM-A8 in green turtle nesting populations across the Atlantic. Samples from Brazil ${ }^{1}$ (3 sites): Atol das Rocas (ATO; $n=53$ ), Fernando de Noronha (NOR; $n=16$ ) and Trindade (TRD; $\left.n=99\right)$; Costa Rica, Tortuguero $^{2}$ (COS; $n=433$ ); Cyprus $^{3,4}$, Dutton unpubl (CYP; $\left.n=48\right)$; Equatorial Guinea, Bioko ${ }^{5}$ (BOI; $n=50$ ); Guinea Bissau, Poilão $^{3,5}$ (BIS; $\left.n=70\right)$; Mexico, X'cacel ${ }^{3}$ (MEX; $\left.n=20\right)$; Principe ${ }^{5}$ (PRI; $n=6$ ), São Tome ${ }^{5}$ (SAO; $n=20$ ); Suriname, Matapica ${ }^{3}$ (SUR; $n=15$ ); UK, Ascension Island ${ }^{6}$ (ASC; $n=245$ ); USA, Florida, Hutchinson Island ${ }^{3}$ (FLR; $n=24$ ); Venezuela, Aves Island ${ }^{7}$ (AVE; $n=30$ ). Black segments of pie charts represent proportion of CM-A8 and charts are sized to indicate the magnitude of each nesting population ${ }^{15-21}$, J. F. Dontaine pers. comm., S. Ahamada pers. comm. (b) Relative frequency of mtDNA haplotype CM-A8 in green turtle foraging ground samples across the Atlantic and estimated contribution of the Poilão rookery based on mixed stock analysis. Black segments of pie charts represent proportion of CM-A 8 and charts are sized proportional to the relative contribution estimated from mixed stock analysis (key to abbreviations, mean contributions, confidence intervals, sample sizes and literature sources are shown in Table 1a). References: ${ }^{1}$ Bjorndal et al. (2006), ${ }^{2}$ Bjorndal, Bolten \& Tröeng (2005), ${ }^{3}$ Encalada et al. (1996), ${ }^{4}$ Kaska (2000), ${ }^{5}$ Formia et al. (2006), ${ }^{6}$ Formia et al. (2007), ${ }^{7}$ Lahanas et al. (1998), ${ }^{8}$ Luke et al. (2004), ${ }^{9}$ Naro-Maciel et al. (2007), ${ }^{10}$ Formia (2002), ${ }^{11}$ Bass \& Witzell (2000), ${ }^{12}$ Bagley (2003), ${ }^{13}$ Bass, Lagueux \& Bowenm (1998), ${ }^{14}$ Bass, Epperly \& Braun-McNeill (2006), ${ }^{15}$ Bellini et al. (1995), ${ }^{16}$ Bellini \& Sanches (1996), ${ }^{17}$ Broderick et al. (2002) ${ }^{18}$ Broderick et al. (2006), ${ }^{19}$ Catry et al. $2002 ;{ }^{20}$ Seminoff $(2002),{ }^{21}$ Tomás, et al. (in press).

respectively); see Fig. S2 (Supporting information) for rasters of individual seasons. Although, it is possible that some hatchlings could become entrained in the very strong and narrow Angola Current which would carry them to the south along the coast of east-central Africa, this was not observed in our model.

\section{GENETICS}

Albeit with small sample sizes, it is clear that the dispersion of adults can be ascertained using satellite tracking very quickly and effectively. But can the dispersion of the numerous annual cohorts of juveniles be inferred from molecular tracking? 
Despite a relatively large number of genetic samples $(n=70)$ analysed from Poilão, the rookery appears to be fixed for a single mtDNA haplotype, CM-A8 (Fig. 3a). When considering the distribution of this haplotype marker in conspecifics in the Atlantic, it appears that CM-A8, although widely distributed in rookeries in West Africa (Poilão, Bioko, Sao Tome and Principe) and the South Atlantic (Ascension Island and Brazil), is not found at all in the breeding aggregations of the wider Caribbean (Surinam, Venezuela, Costa Rica, Mexico or Florida) or Mediterranean (Fig. 3a). Although this dichotomy is not quite so marked, it is somewhat iterated in the picture of the neritic foraging ground profiles (Fig. 3b). Although it is common in West Africa and Brazil, and a significant minority of the haplotypes in Barbados are CM-A8 (14 of 60 samples), in the majority of the wider Caribbean and North American samples analysed to date, CM-A8 is rare or absent. Qualitatively, therefore, it seems likely that the development and foraging grounds for the Poilão population would be limited to the southwestern or eastern Atlantic. Quantitative analysis, however, only very weakly supported this pattern. When molecular data were subject to a mixed stock analysis, although the estimated contribution of Poilão turtles was slightly higher in foraging areas in the south and east Atlantic, no foraging ground described to date seemed to have Poilão as its major contributing rookery. Mean estimated contributions ranged from negligible levels to $5 \cdot 7 \%$ for the samples gathered from turtles captured in fisheries on the African coast from Liberia to Benin (Table 1-a; Fig. 3b).

The distribution shown in the molecular data is likely to be defined in large part by the original dispersal of hatchlings and small pelagic juveniles after leaving the nesting beach. Could it be, as suggested by our current modelling that there is a near dichotomous split between our population of interest in the eastern Atlantic and those breeding at the other side of the basin? If we use this as prior information and carry out mixed stock analysis for the eastern Atlantic only, we find that Poilão contributes at a higher level $(8 \%, 10 \%$ and $12 \%$ to the regional foraging areas of Corisco, Sao Tome and Liberia-Benin, respectively; Table 1-b).

\section{Discussion}

Utilization of three very different yet synergistic methodologies offers significant insights into fundamental and applied aspects of the movements and distribution of individuals from this population. Until this study, other than six flipper tag returns away from the rookery, we had no knowledge of the spatial ecology of the largest nesting aggregation of green turtles in the eastern Atlantic. Our primary aim was to define the habitat utilization using satellite tracking. We have demonstrated that although all individuals stay relatively close to the nesting colony between clutches, they are quite variable in their post-nesting dispersal patterns. The pattern of dispersal can be classified as a coastal (type A; Godley et al. 2008) and is similar in form and distances travelled $754 \mathrm{~km}(411-1470 \mathrm{~km})$ to that exhibited by another continental nesting population in Costa Rica (Tröeng et al. 2005) with individuals radiating northwards from the nesting site. Previous tracking of conspecifics from more remote island rookeries generally travelled further to foraging areas [Ascension Island: 2749 km (2334-3025 km; Hays et al. 2001, 2002; Cyprus: 1364 km (322-2199 km; Godley et al. 2002)]. Interestingly, in contrast to most individuals previously tracked along continents, the four turtles migrating to Mauritania all travelled, at least in part, through oceanic waters. It may be that turtles were affected by the flow or other conditions created by the waters of the Gambia River.

We demonstrate here that habitat connectivity for marine conservation is possible. It is gratifying, given the relative paucity of marine protected areas in West Africa, that two such areas: the João Viera e Poilão National Marine Park (Guinea Bissau) and the Banc d'Arguin National Park (Mauritania) should show demonstrable linked importance for breeding and feeding. For adult females, it may be that with a limited amount of additional research, key foraging areas can be defined that, with effective management, will form a core to help safeguard the species in the region. Similar work on conspecifics in the Mediterranean has highlighted several key foraging areas within the region, with females showing fidelity to these sites within and between seasons (Broderick et al. 2007). This is a relatively easy task for large adults that can be tracked from breeding colonies to foraging areas but what of the juvenile foraging areas? Where are the animals from this population likely to be in the years between hatchling and adulthood?

Upon hatching, turtles make their way to the sea and assuming that neonate hatchlings are positively buoyant (Witherington 2002) and effectively passive (Bolten 2003b), dispersal is likely to be heavily constrained in this region as a result of the prevailing currents. Our current model suggests that the majority of virtual neonates are retained within the Gulf of Guinea region but span from Mauritania to Sao Tome and Principe. All known adult movements (flipper tag returns or satellite tracks) were very localized or northwards but these data are limited and although green turtles can show extended fidelity to foraging areas, they are also known to make sequential ontogenic shifts between feeding habitats (Meylan 1995).

Our genetic data show that although marine turtle foraging grounds may be populated by mixed stocks (Lahanas et al. 1998), the situation is far from panmixia. Regional assemblages may be subject to profound substructuring within ocean basins; with the main concentrations of genetic stocks being much more local to the nesting grounds than has been supposed based around the model of the loggerhead turtles from North America breeding stocks, which is profoundly influenced by the proximity of many breeding areas to the Gulf Stream current. The life-cycle of these loggerheads appears to take them across much of the North Atlantic (Musick \& Limpus 1997; Laurent et al. 1998; Bolten 2003a,b) although genetic evidence (Bowen et al. 2004, Bolker et al. 2007) suggests that sub regional natal homing is present in larger juveniles that is also mirrored by adult distribution patterns demonstrated by tracking (Godley et al. 2008). Discrete stocks are not without precedent. Recent molecular profiling in Hawaii has suggested that all green turtles in the archipelago 
Table 1. Mean contribution from Poilão to (a) 14 different foraging areas across the Atlantic assuming panmixia (b) three foraging areas in the eastern Atlantic assuming no contribution from central and western Atlantic. We include upper and lower confidence intervals (CI), sample sizes and data sources

\begin{tabular}{|c|c|c|c|}
\hline Foraging ground & $\begin{array}{l}\text { Mean, } \\
n(\%)\end{array}$ & $\begin{array}{l}\text { Lower, } \\
2 \cdot 5 \% \mathrm{CI}\end{array}$ & $\begin{array}{l}\text { Upper, } \\
97 \cdot 5 \% \text { CI }\end{array}$ \\
\hline \multicolumn{4}{|l|}{ (a) } \\
\hline Bahamas, Great Inagua (BAH; $n=79^{7}$ ) & $0 \cdot 25$ & $0 \cdot 00$ & $2 \cdot 42$ \\
\hline Barbados $\left(\mathrm{BAR} ; n=60^{8}\right)$ & $1 \cdot 82$ & $0 \cdot 00$ & $16 \cdot 64$ \\
\hline Brazil, Almofala (ALM; $\left.n=131^{9}\right)$ & $1 \cdot 37$ & $0 \cdot 00$ & $13 \cdot 78$ \\
\hline Brazil, Atol das Rocas (ATL; $n=32^{1}$ ) & $1 \cdot 15$ & $0 \cdot 00$ & $12 \cdot 54$ \\
\hline Brazil, Ubatuba (UBA; $\left.n=117^{9}\right)$ & $3 \cdot 49$ & $0 \cdot 00$ & $31 \cdot 19$ \\
\hline $\begin{array}{l}\text { Equatorial Guinea/Gabon, Corisco Bay } \\
\left(\operatorname{COR} ; n=239^{10}\right)\end{array}$ & $1 \cdot 51$ & $0 \cdot 00$ & $17 \cdot 41$ \\
\hline USA, Florida, Hutchinson Island (HI; $n=62^{11}$ ) & $0 \cdot 11$ & $0 \cdot 00$ & $1 \cdot 15$ \\
\hline USA, Florida, Indian River (IR; $n=100^{2}$ ) & $0 \cdot 36$ & $0 \cdot 00$ & $3 \cdot 39$ \\
\hline USA, Florida, Worm Rock Reef (WRR; $n=100^{12}$ ) & $0 \cdot 15$ & $0 \cdot 00$ & $1 \cdot 58$ \\
\hline USA, Florida, Trident Basin $\left(\mathrm{TB} ; n=100^{12}\right)$ & $0 \cdot 07$ & $0 \cdot 00$ & $0 \cdot 76$ \\
\hline Nicaragua (NIC; $n=60^{13}$ ) & $0 \cdot 12$ & $0 \cdot 00$ & $1 \cdot 20$ \\
\hline Sao Tome $\left(\mathrm{SAO} ; n=75^{10}\right)$ & $3 \cdot 62$ & $0 \cdot 00$ & $35 \cdot 06$ \\
\hline Liberia to Benin (L-B; $n=62^{10}$ ) & $5 \cdot 74$ & $0 \cdot 00$ & $48 \cdot 01$ \\
\hline USA, North Carolina (NC; $\left.n=106^{14}\right)$ & $1 \cdot 27$ & $0 \cdot 00$ & $8 \cdot 47$ \\
\hline \multicolumn{4}{|l|}{ (b) } \\
\hline \multicolumn{4}{|l|}{ Equatorial Guinea/Gabon, Corisco Bay $\left(n=239^{10}\right)$} \\
\hline Bioko & $47 \cdot 14$ & $0 \cdot 05$ & $83 \cdot 85$ \\
\hline Poilão & $7 \cdot 65$ & $0 \cdot 00$ & $41 \cdot 18$ \\
\hline Sao Tome & $38 \cdot 83$ & $0 \cdot 29$ & $85 \cdot 26$ \\
\hline Principe & $6 \cdot 38$ & $0 \cdot 00$ & $40 \cdot 39$ \\
\hline \multicolumn{4}{|l|}{ Sao Tome $\left(n=75^{10}\right)$} \\
\hline Bioko & $17 \cdot 49$ & $0 \cdot 00$ & $61 \cdot 80$ \\
\hline Poilão & $10 \cdot 22$ & $0 \cdot 00$ & 48.79 \\
\hline Sao Tome & $27 \cdot 59$ & $0 \cdot 00$ & $86 \cdot 29$ \\
\hline Principe & $44 \cdot 70$ & $0 \cdot 03$ & $94 \cdot 45$ \\
\hline \multicolumn{4}{|l|}{ Liberia to Benin $\left(n=62^{10}\right)$} \\
\hline Bioko & $43 \cdot 60$ & $0 \cdot 00$ & $95 \cdot 34$ \\
\hline Poilão & $12 \cdot 35$ & $0 \cdot 00$ & $58 \cdot 90$ \\
\hline Sao Tome & $23 \cdot 74$ & $0 \cdot 00$ & $88 \cdot 06$ \\
\hline Principe & $20 \cdot 31$ & $0 \cdot 00$ & $90 \cdot 21$ \\
\hline \multicolumn{4}{|l|}{ All eastern Atlantic $\left(n=376^{10}\right)$} \\
\hline Bioko & $32 \cdot 41$ & $0 \cdot 00$ & $72 \cdot 10$ \\
\hline Poilão & 8.93 & 0.00 & $42 \cdot 86$ \\
\hline Sao Tome & $39 \cdot 32$ & $0 \cdot 01$ & $92 \cdot 62$ \\
\hline Principe & $19 \cdot 34$ & $0 \cdot 00$ & $68 \cdot 75$ \\
\hline
\end{tabular}

References: ${ }^{1}$ Bjorndal et al. (2006), ${ }^{2}$ Bjorndal, Bolten and Tröeng (2005), ${ }^{3}$ Encalada et al. (1996), ${ }^{4}$ Kaska (2000), ${ }^{5}$ Formia et al. (2006), ${ }^{6}$ Formia et al. (2007), ${ }^{7}$ Lahanas et al. (1998), ${ }^{8}$ Luke et al. (2004), ${ }^{9}$ Naro-Maciel et al. (2007), ${ }^{10}$ Formia (2002), ${ }^{11}$ Bass and Witzell (2000), ${ }^{12}$ Bagley (2003), ${ }^{13}$ Bass, Lagueux and Bowenm (1998), ${ }^{14}$ Bass, Epperly and BraunMcNeill (2006), ${ }^{15}$ Bellini et al. (1995), ${ }^{16}$ Bellini and Sanches (1996), ${ }^{17}$ Broderick et al. (2002) ${ }^{18}$ Broderick et al. (2006), ${ }^{19}$ Catry et al. $2002 ;{ }^{20}$ Seminoff $(2002),{ }^{21}$ Tomás, et al. (in press). originate from the French Frigate Shoals (Dutton et al. 2008). It may be that such profound substructuring, once clearly defined, can greatly enhance the development of stock-specific management plans.

Molecular methods potentially present a degree of insight into the likely patterns of the dispersal of widely distributed species such as marine turtles. In our analyses, although genetics alone suggested a likelihood that Poilão had a greater influence in African coastal stocks than those in the western Atlantic, the relationship was not quite as strong as might be expected given Poilão is probably the largest green turtle rookery in West Africa (Catry et al. 2002, 2009). There are, however, a few caveats that need to be borne in mind for the interpretation here. Firstly, Poilão appears fixed for the widespread, possibly ancestral CM-A8 haplotype, despite a relatively large sample size which could, of course, be improved to ensure exhaustive capture of haplotype diversity. Higher resolution markers (e.g. microsatellites) would offer greater power to detect patterns of movement and stock composition as well as offering insights into male-mediated gene-flow (Roberts, Schwartz \& Karl 2004). In addition, although we have comprehensively reviewed the available literature for genetic studies of nesting sites and foraging grounds, coverage is far from complete and this element would be strengthened by increased spatial resolution of sampling. For instance, the haplotype composition of foraging stocks for all of West Africa to the 
north of Guinea-Bissau is yet unknown although tracking and tagging data suggest that the genetic makeup is likely to reflect that of Poilão. Both our analysis and that of Bolker et al. (2007) are indicative of the absence of the description of one or more major foraging areas. Although technically and logistically demanding, the benefit of further genetic sampling to include the population segments missing from our analyses (i.e. additional nesting colonies, turtles from oceanic habitats and from additional foraging grounds in Atlantic Africa and South America) is clear. Molecular sampling is more complete for hawksbill turtles Eretmochelys imbricata Linnaeus in the Caribbean and molecular profiles were found to closely concord with those generated using a similar particle model of hatchling dispersal across the region (Blumenthal et al. 2009).

There are several complicating issues in using GVV to model particle movement and thus offer insights into likely hatchling dispersal patterns. Firstly, they are calculated primarily for waters off the continental shelf and are not therefore present for coastal waters which causes advection trajectories to breakdown when animals move near the coast. Secondly, although drift is highly correlated with geostrophic flows (Hays \& Marsh 1997) variable, ageostrophic flows such as Ekman components will also contribute to hatchling drift (Rio \& Hernandez 2003) and need to be integrated in future models. Thirdly, in our heuristic model, we assume particles are completely passive. Although this may effectively be true in the first days post-hatching dispersal, it is likely that as turtles grow they have a more and more active role in directing their movements. The modelled distribution from a passive model, however, is still likely to be indicative of the influence of currents on early distribution. A final point is that the study region around the Gulf of Guinea is oceanographically very complex which offers challenges to current modelling, especially with regard to blending of different oceanographic models around the equator (Lagerloef et al. 1999).

In summary, using integrated multiple approaches we suggest that, as a result of prevailing oceanographic conditions, the West African green turtle stocks nesting at Poilão, Guinea Bissau may be largely concentrated in the oceanic and neritic waters of the tropical eastern Atlantic. We suggest that the triplet of methods (satellite tracking, genetics and oceanic current modelling) presented here is a very good starting point for the rapid assessment of likely geographic range of such species. This could be further augmented using chemical markers such as stable isotopes or trace elements (Webster et al. 2002). This latter approach is already underway for marine turtles (McClellan et al. 2010).

\section{Acknowledgements}

This project has benefited from the support of many individuals and institutions. We would particularly like to acknowledge the support given by Pierre Campredon (FIBA), Nelson Gomes Dias (IUCN), Alfredo Simão da Silva (GPC), Justino Biai and the staff from the Bijagós Biosphere Reserve (BBR) as well as all the staff from the Orango National Park. This work would not have been possible without the support of the people from the village of Ambeno (island of Canhabaque), the traditional owners of the sacred island of Poilão, especially Januário da Silva and Preto João Pereira. Amadeu Almeida and Bucar Indjai assisted with fieldwork. The work was funded by the Convention on
Migratory Species, Darwin Initiative, European Union Marie Curie Training and Mobility of Researchers Programme, European Social Fund, Fondation Internationale du Banc d'Arguin (FIBA), Large Pelagics Research Center at the University of New Hampshire (through National Oceanographic and Atmospheric Agency award NA04NMF4550391), People's Trust for Endangered Species and the Natural Environment Research Council (Fellowship to BJG). Fundação para a Ciência e Tecnologia (FCT-Portugal) as part of the Programa Plurianual (UI\&D 331/94) and through grants to PC. The altimeter products were produced by Ssalto/Duacs as part of the Environment and Climate EU Enact project (EVK2-CT2001-00117) and distributed by Aviso, with support from CNES (http://www.jason.oceanobs.com/html/donnees/duacs/ processing_uk.html\#publi). The manuscript was improved by the comments of Janice Blumenthal, Matthew Godfrey, Kartik Shanker and two anonymous reviewers.

\section{References}

Åkesson, S. \& Alerstam, T. (1998) Oceanic navigation: are there any feasible geomagnetic bi coordinate combinations for albatrosses? Journal of Avian Biology, 29, 618-625.

Avise, J.C. (1998) Conservation genetics in the marine realm. The Journal of Heredity, 89, 377-382.

Bagley, D.A. (2003) Characterizing Juvenile Green Turtles (Chelonia Mydas) From Three East Central Florida Developmental Habitats. MS thesis, University of Central Florida, Orlando, FL, USA.

Balazs, G.H. \& Chaloupka, M. (2004) Thirty-year recovery trend in the once depleted Hawaiian green sea turtle stock. Biological Conservation, 117, 491498

Bass, A.L., Lagueux, C.J. \& Bowenm, B.W. (1998) Origin of green turtles, Chelonia mydas, at "Sleeping rocks" off the Northeast coast of Nicaragua. Copeia, 1998, 1064-1069.

Bass, A.L. \& Witzell, W.N. (2000) Demographic composition of immature green turtles (Chelonia mydas) from the East Central Florida coast: evidence from mtDNA makers. Herpetologica, 56, 357-367.

Bearhop, S., Fiedler, W., Furness, R.W., Votier, S.C., Waldron, S., Newton, J., Bowen, G.J., Berthold, P. \& Farnsworth, K. (2005) Assortative mating as a mechanism for rapid evolution of a migratory divide. Science, 310, 502-504.

Bellini, C. \& Sanches, T.M. (1996) Reproduction and feeding of marine turtles in the Fernando de Noronha Archipelago, Brazil. Marine Turtle Newsletter, 74, 12-13.

Bellini, C., Marcovaldi, M.Â., Sanches, T.M., Grossman, A. \& Sales, G. (1995) Atol das Rocas Biological Reserve: second largest Chelonia rookery in Brazil. Marine Turtle Newsletter, 72, 1-2.

Bjorndal, K.A., Bolten, A.B. \& Tröeng, S. (2005) Population structure and genetic diversity in green turtles nesting at Tortuguero, Costa Rica, based on mitochondrial DNA control region sequences. Marine Biology, 147, 1449 1457.

Bjorndal, K.A., Bolten, A.B., Moreira, L., Bellini, C. \& Marcovaldi, M.A. (2006) Population structure and diversity of Brazilian Green Turtle rookeries based on mitochondrial DNA sequences. Chelonian Conservation and Biology, 5, 262-268.

Block, B.A., Teo, S.L.H., Walli, A., Boustany, A., Stokjesbury, M.J.W., Farwell, C.J., Weng, K.C., Dewar, H. \& Williams, T.D. (2005) Electronic tagging and population structure of Atlantic blue fin tuna. Nature, 434, $1121-1127$

Blumenthal, J.M., Abreu-Grobois, F.A., Austin, T.J., Broderick, A.C., Bruford, M.W., Coyne, M.S., Ebanks-Petrie, G., Formia, A., Meylan, P.A., Meylan, A.B. \& Godley, B.J. (2009) Turtle groups or turtle soup: dispersal patterns of hawksbill turtles in the Caribbean. Molecular Ecology, 18, 48414853.

Bolker, B., Okuyama, T., Bjorndal, K.A. \& Bolten, A.B. (2003) Sea turtle stock estimation using genetic markers: accounting for sampling error of rare genotypes. Ecological Applications, 13, 763-775.

Bolker, B.M., Okuyama, T., Bjorndal, K.A. \& Bolten, A.B. (2007) Incorporating multiple mixed stocks in mixed stock analysis: 'many-to-many' analyses. Molecular Ecology, 16, 685-695.

Bolten, A.B. (2003a) Variation in sea turtle life history patterns: neritic v oceanic developmental stages. The Biology of Sea Turtles Volume II (eds P.L. Lutz, J.A. Musick \& J. Wyneken), pp. 243-258. CRC Press, Boca Raton, FL.

Bolten, A.B. (2003b) Active swimmers - passive drifters: the oceanic juvenile stage of loggerhead in the Atlantic system. Loggerhead Sea Turtles (eds A.B. Bolten \& B.E. Witherington), pp. 63-78. Smithsonian Institution Press, Washington. 
Bolten, A.B., Bjorndal, K.A., Martins, H.R., Dellinger, T., Biscoito, M.J., Encalada, S.E. \& Bowen, B.W. (1998) Transatlantic developmental migrations of loggerhead sea turtles demonstrated by mtDNA sequence analysis. Ecological Applications, $8,1-7$.

Bowen, B.W., Meylan, A.B., Ross, J.P., Limpus, C.J., Balazs, G.H. \& Avise, J.C. (1992) Global population structure and natural history of the green turtle (Chelonia mydas) in terms of matriarchal phylogeny. Evolution, 46, 865-881.

Bowen, B.W., Kamezaki, N., Limpus, C.J., Hughes, G.R., Meylan, A.B. \& Avise, J.C. (1994) Global phylogeography of the loggerhead turtle (Caretta caretta) as indicated by mitochondrial DNA haplotypes. Evolution, $\mathbf{4 8}$, 1820-1828.

Bowen, B.W., Abreu-Grobois, F.A., Balazs, G.H., Kamezaki, N., Limpus, C.J. \& Ferl, R.J. (1995) Trans-Pacific migrations of the loggerhead turtle (Caretta caretta) demonstrated with mitochondrial DNA markers. Proceedings of the National Academy of Science, 92, 3731-3734.

Bowen, B.W., Bass, A.L., Chow, S.M., Bostrom, M., Bjorndal, K.A., Bolten, A.B., et al. (2004) Natal homing in juvenile loggerhead turtles (Caretta caretta). Molecular Ecology, 13, 3797-3808.

Bowen, B.W., Clark, A.M., Abreu-Grobois, F.A., Chaves, A., Reichart, H.A. \& Ferl, R.J. (1998) Global phylogeography of the ridley sea turtles (Lepidochelys spp.) as inferred from mitochondrial DNA sequences. Genetica, 101, 179-189.

Bowen, B.W., Grant, W.S., Hillis-Starr, Z., Bjorndal, K.A., Boton, A.B. \& Bass, A.L. (2007) Mixed-stock analysis reveals the migrations of juvenile hawksbill turtles (Eretmochelys imbricata) in the Caribbean sea. Molecular Ecology, 16, 49-60.

Broderick, A.C., Glen, F., Godley, B.J. \& Hays, G.C. (2002) Estimating the number of green and loggerhead turtles nesting annually in the Mediterranean. Oryx, 36, 227-235.

Broderick, A.C., Frauenstein, R., Fiona Glen, F., Hays, G.C., Jackson, A.L., Pelembe, T., Ruxton, G.D. \& Godley, B.J. (2006) Are green turtles globally endangered? Global Ecology and Biogeography, 15, 21-26.

Broderick, A.C., Coyne, M.S., Fuller, W.J., Glen, F. \& Godley, B.J. (2007) Fidelity and overwintering of sea turtles. Proceedings of the Royal Society $B$, 274, 1533-1538.

Catry, P., Barbosa, C., Indjai, B., Almeida, A., Godley, B.J. \& Vie, J.C. (2002) First census of the green turtle at Poilão, Bijagos Archipelago, Guinea-Bissau: the most important nesting colony on the Atlantic coast of Africa. Oryx, 36, 400-403.

Catry, P., Barbosa, C., Paris, B., Indjai, B., Almeida, A., Limoges, B., Silva, C \& Pereira, H. (2009) Status, ecology and conservation of sea turtles in Guinea-Bissau. Chelonian Conservation and Biology, 8, 150-160.

Cooke, S.J. (2008) Biotelemetry and biologging in endangered species research and animal conservation: relevance to regional, national, and IUCN Red List threat assessments. Endangered Species Research, 4, 165-185.

Coyne, M.S. \& Godley, B.J. (2005) Feature article: satellite tracking and analysis tool (STAT): an integrated system for archiving, analyzing and mapping animal tracking data. Marine Ecology Progress Series, 301, 1-7.

Dutton, P.H., Bowen, B.W., Owens, D.W., Barragan, A. \& Davis, S.K. (1999) Global phylogeography of the leatherback turtle (Dermochelys coriacea). Journal of Zoology, 248, 397-409.

Dutton, P.H., Balazs, G.H., LeRoux, R.A., Murakawa, S.K.K., Zarate, P. \& Martínez, L.S. (2008) Composition of Hawaiian green turtle foraging aggregations: mtDNA evidence for a distinct regional population. Endangered Species Research, 5, 37-44.

Encalada, S.E., Lahanas, P.N., Bjorndal, K.A., Bolten, A.B., Miyamoto, M.M. \& Bowen, B.W. (1996) Phylogeography and population structure of the Atlantic and Mediterranean green turtle Chelonia mydas: a mitochondrial DNA control region sequence assessment. Molecular Ecology, 5, 473483.

FitzSimmons, N.N., Moritz, C., Limpus, C.J., Pope, L. \& Prince, R. (1997a) Geographic structure of mitochondrial and nuclear gene polymorphisms in Australia green turtle populations and male-biased gene flow. Genetics, 147, 1843-1854.

FitzSimmons, N.N., Limpus, C.J., Norman, J.A., Goldizen, A.R., Miller., J.D. \& Moritz, C. (1997b) Philopatry of male marine turtles inferred from mitochondrial DNA markers. Proceedings of the National Academy of Science USA, 94, 8912-8917.

Formia, A. (2002) Population and Genetic Structure of the Green Turtle (Chelonia Mydas) in West and Central Africa; Implications for Management and Conservation. $\mathrm{PhD}$ Thesis, Cardiff University, UK.

Formia, A., Godley, B.J., Dontaine, J.-F. \& Bruford, M.W.C. (2006) Mitochondrial DNA diversity and phylogeography of endangered green tur- tle Chelonia mydas) populations in Africa. Conservation Genetics, 7, 353369.

Formia, A., Broderick, A.C., Glen, F., Godley, B.J., Hays, G.C. \& Bruford, M.W. (2007) Genetic composition of the Ascension Island green turtle rookery based on mitochondrial DNA: implications for sampling and diversity. Endangered Species Research, 3, 145-158.

Godley, B.J., Richardson, S., Broderick, A.C., Coyne, M.S., Glen, F. \& Hays, G.C. (2002) Long-term satellite telemetry of the movements and habitat utilisation by green turtles in the Mediterranean. Ecography, 25, 352-362.

Godley, B.J., Blumenthal, J.M., Broderick, A.C., Coyne, M.S., Godfrey, M.H., Hawkes, L.A. \& Witt, M.J. (2008) Review: Satellite tracking of sea turtles: where have we been and where do we go next? Endangered Species Research, 4, 3-22.

Hamann, M., Godfrey, M. H., Seminoff, J. A., Arthur, K., Barata, P.C.R. \& Bjorndal, K.A. et al. (in press) Global research priorities for sea turtles: informing management and conservation in the 21st century. Endangered Species Research.

Hawkes, L.A., Broderick, A.C., Coyne, M.S., Godfrey, M.S., Lopez- Jurado, L.F., Lopez-Suarez, P., Merino, S.E., Varo-Cruz, N. \& Godley, B.J. (2006) Phenotypically linked dichotomy in sea turtle foraging requires multiple conservation approaches. Current Biology, 16, 990-995.

Hays, G.C. \& Marsh, R. (1997) Estimating the age of juvenile loggerhead sea turtles in the North Atlantic. Canadian Journal of Zoology, 75, 40-46.

Hays, G.C., Godley, B.J., Broderick, A.C., Glen, F. \& Nicholls, W.J. (2001) The movements and submergence behaviour of male green turtles at Ascension Island. Marine Biology, 139, 395-399.

Hays, G.C., Broderick, A.C., Godley, B.J., Lovell, P., Martin, C., McConnell, B.J. \& Richardson, S. (2002) Bi-phasal long-distance migration in green turtles. Animal Behaviour, 64, 895-898

James, M.C., Ottensmeyer, C.A. \& Myers, R.A. (2005) Identification of highuse habitat and threats to leatherback sea turtles in northern waters: new directions for conservation. Ecology Letters, 8, 195-201.

Kaska, Y. (2000) Genetic structure of Mediterranean sea turtle populations. Turkish Journal of Zoology, 24, 191-197.

Lagerloef, G.S.E., Mitchum, G.T., Lukas, R.B. \& Niiler, P.P. (1999) Tropical Pacific near surface currents estimated from altimeter, wind and drifter data. Journal of Geophysical Research, 104, 23313-23326.

Lahanas, P.N., Bjorndal, K.A., Bolten, A.B., Encalada, S.E., Miyamoto, M.M., Valverde, R.A. \& Bowen, B.W. (1998) Genetic composition of a green turtle (Chelonia mydas) feeding ground population: evidence of multiple origins. Marine Biology, 130, 345-352.

Laurent, L., Casale, P., Bradai, M.N., Godley, B.J., Gerosa, G., Broderick, A.C., Schroth, W., Shierwater, B., Levy, A.M., Freggi, D., Abd El-Mawla, N.E.M., Hadoud, D.A., Gomati, H.E., Domingo, M., Hadjichristophorou, M., Kornaraky, L., Demirayak, F. \& Gautier, Ch. (1998) Molecular resolution of marine turtle stock composition in fishery bycatch: a case study in the Mediterranean. Molecular Ecology, 7, 1529-1542.

Luke, K., Horrocks, J.A., LeRoux, R.A. \& Dutton, P.H. (2004) Origins of green turtle (Chelonia mydas) feeding aggregations around Barbados, West Indies. Marine Biology, 144, 799-805.

Luschi, P., Hays, G.C., del Seppia, C., Marsh, R. \& Papi, F. (1998) The navigational feats of green sea turtles migrating from Ascension Island investigated by satellite telemetry. Proceedings of the Royal Society (B), 265, 2279-2284

Lutcavage, M.E., Brill, R.W., Skomal, G.B., Chase, B.C., Goldstein, J.L. \& Tutein, J. (2000) Tracking adult North Atlantic bluefin tuna (Thunnus thynnnus) in the northwestern Atlantic using ultrasonic telemetry. Marine Biology, $137,347-358$

Masuda, M. (2001) User's Manual for BAYES Stock-Mixture Analysis Program Based on Bavesian Methods. National Marine Fisheries Service, Alaska Fisheries Science Center, USA.

Mate, B.R., Nieukirk, S.L. \& Kraus, S.D. (1997) Satellite-monitored movements of the Northern Right whale. The Journal of Wildlife Management, 61, 1393-1405.

McClellan, C.M. \& Read, A.J. (2007) Complexity and variation in loggerhead sea turtle life history. Biology Letters, 3, 592-594.

McClellan, C.M., Braun-McNeill, J., Avens, J., Wallace, B.P. \& Read, A.J. (2010) Stable isotopes confirm a foraging dichotomy in juvenile loggerhead sea turtles. Journal of Experimental Marine Biology and Ecology, 387, 44-51.

Meylan, A. (1995) Sea turtle migration - evidence from tag returns. Biology and Conservation of Sea Turtles (ed. K.A. Bjorndal), pp. 91-103. Smithsonian Institution Press, Washington, DC, USA.

Meylan, A.B., Bowen, B.W. \& Avise, J.C. (1990) A genetic test of the natal homing versus social facilitation models for green turtle migration. Science, 248, 724-727. 
Moritz, C. (1994) Applications of mitochondrial DNA analysis in conservation: a critical review. Molecular Ecology, 3, 401-411.

Musick, J.A. \& Limpus, C.J. (1997) Habitat utilisation and migration in juvenile sea turtles. The Biology of Sea Turtles (eds P.L. Lutz \& J.A. Musick), pp. 137-165. CRC Press, Boca Raton.

Naro-Maciel, E., Becker, J.H., Lima, E.H.S.M., Marcovaldi, M.A. \& DeSalle, R. (2007) Testing dispersal hypotheses in foraging green sea turtles (Chelonia mydas) of Brazil. Journal of Heredity, 98, 29-39.

Palumbi, S.R. \& Cipriamo, F. (1998) Species identification using genetic tools: the value of nuclear and mitochondrial gene sequences in whale conservation. Journal of Heredity, 89, 459-464.

Parsons, J.J. (1962) The Green Turtle and man. University of Florida Press, Gainesville, FL, USA.

Pella, J. \& Masuda, M. (2001) Bayesian methods for analysis of stock mixtures from genetic characters. Fisheries Buletin, 99, 151-167.

Rio, M.H. \& Hernandez, F. (2003) High-frequency response of wind-driven currents measured by drifting buoys and altimetry over the world ocean. Journal of Geophysical Research, 108, 3283.

Roberts, M.A., Schwartz, T.S. \& Karl, S.A. (2004) Global population genetic structure and male-mediated gene flow in the green sea turtle (Chelonia mydas): analysis of microsatellite loci. Genetics, 166, 1857-1870.

Seminoff, J.A. (2002) 2002 IUCN Red List Global Status Assessment: Green Turtle (Chelonia mydas). IUCN/SSC Marine Turtle Specialist Group, Gland, Switzerland.

Seminoff, J.A., Zárate, P., Coyne, M.S., Foley, D.G., Parker, D., Lyon, B. \& Dutton, P.H. (2008) Post-nesting migrations of Galapagos green turtles, Chelonia mydas, in relation to oceanographic conditions of the Eastern Tropical Pacific Ocean: integrating satellite telemetry with remotely-sensed ocean data. Endangered Species Research, 4, 57-72.

Thompson, D., Moss, S.E.W. \& Lovell, P. (2003) Foraging behaviour of South American fur seals Arctocdephalus australis; extracting fine scale behaviour from satellite tracks. Marine Ecology Progress Series, 260, 285-296.

Tomás, J., Godley, B.J., Castroviejo, J. \& Raga, J.A. (in press) Critically important nesting habitat for sea turtles of West Africa. Biodiversity and Conservation.

Tröeng, S. \& Rankin, E. (2005) Long term conservation efforts contribute to positive green turtle (Chelonia mydas) nesting trend at Tortuguero, Costa Rica. Biological Conservation, 121, 111-116.

Tröeng, S., Evans, D.R., Harrison, E. \& Lagueux, C.J. (2005) Migration of green turtles Chelonia mydas from Tortuguero Costa Rica. Marine Biology, 148, 435-447.
Webster, M.S., Marra, P.P., Haig, S.M., Bensch, S. \& Holmes, R.T. (2002) Links between worlds: unraveling migratory connectivity. Trends in Ecology \& Evolution, 17, 76-83.

Wessel, P. \& Smith, W.H.F. (1991) Free software helps map and display. EOS Trans. $A G U, \mathbf{7 2}, 445-446$.

Witherington, B.E. (2002) Ecology of neonate loggerhead turtles inhabiting lines of downwelling near a Gulf Stream front. Marine Biology, 140, 843853.

Received 14 October 2009; accepted 29 March 2010

Handling Editor: J. Matthiopoulos

\section{Supporting Information}

Additional Supporting Information may be found in the online version of this article.

Fig. S1. Animation of the tracks of 861 virtual hatchlings after deployment (2005/2006) in modelled oceanic locations around Poilão, Guinea-Bissau and advection on a dynamic ocean current field for a maximum duration of 850 days.

Fig. S2. The distribution of virtual hatchlings after deployment in modelled oceanic locations around Poilão, Guinea Bissau. Particles were released during six different years (2001/2002 to 2006/2007) and advected on a dynamic ocean current field for a maximum duration of 850 days.

As a service to our authors and readers, this journal provides supporting information supplied by the authors. Such materials may be re-organized for online delivery, but are not copy-edited or typeset. Technical support issues arising from supporting information (other than missing files) should be addressed to the authors. 